\title{
Drinking water treatment by iron anode-based electrocoagulation: humic acids and arsenic removal
}

\author{
A. Pop ${ }^{1}$, C. Bordianu ${ }^{1}$, R. Pode ${ }^{1}$, I. Vlaicu ${ }^{2}$, N. Lungar ${ }^{2}$, \\ K. Bodor ${ }^{2} \&$ F. Manea ${ }^{1}$ \\ ${ }^{1}$ Politehnica University of Timisoara, Romania \\ ${ }^{2}$ SC Aquatim SA Timisoara, Romania
}

\begin{abstract}
Electrocoagulation (EC) represents an alternative to the conventional coagulation process in water treatment in low-capacity plants. Besides the electrode materials, the performance of electrocoagulation is strongly dependent on the raw water matrix. A systematic study has been conducted in this paper in order to optimize the electrocoagulation process operation using iron anode for groundwater with high organic loading and arsenic. The optimization of electrocoagulation parameters was performed, focusing on initial concentration of arsenic and humic acid, current density, the presence of major ions dissolved in water $\left(\mathrm{SO}_{4}{ }^{2-}, \mathrm{Cl}^{-}\right)$. Humic substances were quantified in terms of absorbance at $254 \mathrm{~nm}$ and total organic carbon (TOC) and the arsenic concentration has been assessed in water samples by atomic absorption spectrometry. To elucidate some mechanistic aspect, SEM/EDAX analysis was performed. A systematic study based on various raw water characteristics has been performed for EC process based on iron electrodes to determine the best operating conditions and also, to identify the limits of this process. The specific energy consumption was calculated in order to demonstrate also the process viability from economical point of view. Various treatment scenarios in relation to raw water characteristics and operation conditions were applied in order to determine the optimal conditions regarding process parameters correlated to the range of water characteristics for the drinking water treatment.
\end{abstract}

Keywords: arsenic and humic acid removal, electrocoagulation, iron anodes. 


\section{Introduction}

The caution envisaging the serious health threats caused by the presence of arsenic $[1,2]$ in groundwater from natural or anthropogenic sources lead to focusing research efforts for a worldwide important issue in finding and selecting appropriate solutions for water treatment in order to provide consumers with safe water with a concentration level of arsenic below $10 \mu \mathrm{g} \mathrm{L}^{-1}$, as recommended by the World Health Organization (WHO) for drinking water [3]. The particularity of each groundwater matrix, the interaction between its components and their influence on the current technologies for drinking water treatment represent a continuous challenge for water treatment operators and researchers. Natural organic matter (NOM) present in raw water in high concentration beside other problems that could raise along treatment flow, the disinfection by-products formation. Also, NOM is able to interact with arsenic and form soluble complexes [4], which could hamper treatment process.

The studies regarding the interactions between arsenic and humic acid (HA) as the main component of NOM in order to optimize the classical coagulation using ferric chloride have been reported $[4,5]$.

Iron oxide sorption and an iron based coagulation process are much studied for arsenic removal. The inhibition effect of HA presence on the arsenic sorption on iron oxides was demonstrated $[4,5]$. The conventional coagulation process is considered to be appropriate for the removal of both arsenic and NOM in a single step [4].

Electrocoagulation could represent a promising solution as an alternative to the classical coagulation process for both arsenic and humic acid removal from water. Individual removal of arsenic [6-9] and NOM [10,11] from groundwater were successfully achieved using aluminium and iron sacrificial electrodes assuring insitu generation of coagulants. Better performances for arsenic removal through the electrocoagulation process were recorded using iron electrodes [12]. The negative influence of NOM on arsenic removal using iron electrodes [13, 14] had previously been reported and the particularity of each result related to the water matrix.

The presence of NOM in water influence the coagulation/flocculation mechanism by affecting the flock formation due to the more negative Zeta potential along the EC process [14]. Several aspects regarding the simultaneous removal of these two pollutants from drinking water by electrocoagulation using aluminium electrodes were clarified by Mohora et al. [14].

Having in view our previous promising results [15] obtained for the removal of arsenic from synthetic and real groundwater through electrocoagulation using iron anodes, the aim of this paper is to find appropriate operational electrocoagulation parameters for simultaneous removal of arsenic and humic acid (regarded as a representative model of NOM) from a water with high content of both toxic/potential toxic compounds.

These experiments can be regarded as prerequisite tests for determination of optimal operation condition for electrocoagulation process for its further 
integration within the drinking water treatment pilot plant designed to treat rich arsenic and natural organic matter groundwater.

\section{Material and methods}

Electrocoagulation experiments were performed using an electrolysis cell of $0.7 \mathrm{~L}$ with an iron anode and a stainless steel cathode disposed horizontally and a DC power supply source (mPP 3040 D, Leapronix). The schematic representation of the experimental set-up was previously reported [16]. The iron anode active area was $107 \mathrm{~cm}^{2}$. In order to minimize the electrode passivation effect, the electrodes were chemically activated by successive alkaline-acidic immersion prior to each use. All the experiments were conducted in a galvanostatic regime. The electrocoagulation process was applied on simulated water containing arsenic and humic acid. Sodium arsenite (Merck) and humic acid (Sigma Aldrich) has been commercial purchased and used to prepare the synthetic water.

The effect of current density on simultaneous removal of As and HA from water by electrocoagulation process was studied at: $10 \mathrm{~A} \cdot \mathrm{m}^{-2}, 15 \mathrm{~A} \cdot \mathrm{m}^{-2}$ and $20 \mathrm{~A} \cdot \mathrm{m}^{-2}$, for a water with arsenic concentration of about $300 \mu \mathrm{g} \cdot \mathrm{L}^{-1}$ and $\mathrm{HA}$ concentration of $40 \mathrm{mg} \cdot \mathrm{L}^{-1}$ corresponding to a dissolved organic carbon (DOC) of maximum $9.74 \mathrm{mg} \mathrm{C} \cdot \mathrm{L}^{-1}$. Prior to being analysed, the water samples were filtered through a $0.45 \mu \mathrm{m}$ pore size filter.

A Varian Cary 100 UV-VIS Spectrophotometer was used to measure the absorbance at the wavelength of $254 \mathrm{~nm}$, and the dissolved organic carbon was assessed using a Total Organic Carbon Analyzer (TOC-L Shimadzu). Arsenic analysis was carried out by Atomic Absorption Spectroscopy (Varian SpectrAA 280FS).

The influence of initial concentration of As and HA on electrocoagulation process was studied at a current density of $10 \mathrm{~A} \cdot \mathrm{m}^{-2}$ in a concentration range between $130 \mu \mathrm{g} \cdot \mathrm{L}^{-1}$ and $300 \mu \mathrm{g} \cdot \mathrm{L}^{-1}$ As and 20-40 $\mathrm{mg} \cdot \mathrm{L}^{-1} \mathrm{HA}$, respectively. As(III) was chosen to be removed from simulated water because it is more difficult to be removed in comparison with $\mathrm{As}(\mathrm{V})$.

The influence of the presence of some anions $\left(\mathrm{Cl}^{-}\right.$and $\left.\mathrm{SO}_{4}{ }^{2-}\right)$ into water on the electrocoagulation process was achieved by comparison between two different supporting electrolytes, i.e., sodium chloride, sodium sulphate and a mixture of sodium chloride and sodium sulphate.

The theoretical dose of dissolved iron along the electrocoagulation process was calculated according to Faraday's law (eqn (1)), where $A$ represents the atomic weight for iron $\left(\mathrm{kg} \cdot \mathrm{mol}^{-1}\right), Q$ represents the amount of current passing the solution mass per unit time $(\mathrm{A} \cdot \mathrm{s})$ determined by eqn $(2), n$ is the number of electrons (equal to 2$), F$ is Faraday's number $\left(96500 \mathrm{C} \cdot \mathrm{mol}^{-1}\right)$ [15].

$$
\begin{array}{r}
m_{\text {theoretical }}=\frac{A \times Q}{n \times F} \\
Q=I \times t
\end{array}
$$


The removal efficiency for As and HA (expressed as absorbance at $254 \mathrm{~nm}$ or in terms of DOC) was calculated with eqn (3), where $C_{i}$ and $C_{f}$ represent the initial and final concentration/absorbance of the determined parameters.

$$
\eta(\%)=\frac{C_{i}-C_{f}}{C_{i}} \times 100
$$

The economic aspects were assessed through specific energy consumption determination (Eq. 4).

$$
W_{s p}=Q \times U
$$

where, $W_{s p}$ represents the specific energy consumption $\left(\mathrm{kW} \cdot \mathrm{h} \cdot \mathrm{m}^{-3}\right)$ and $\mathrm{U}$ represents the cell voltage.

The scanning electron microscope in conjunction with energy dispersive X-ray spectroscopy (SEM/EDX, inspection PANalytical) was used to characterize the dried sludge from the electrocoagulation process.

\section{Results and discussion}

\subsection{Influence of current density on simultaneous As and HA removal}

Simultaneous removal of As and HA from water with high content in both of these contaminants by electrocoagulation was performed under galvanostatic regime. The current density is the most important operating parameter that influence the electrocoagulation process performances by controlling the reaction rate [17] within electrolysis cell. According to Faraday's law, the concentration of in-situ iron generated coagulant is directly dependent on the current density applied to electrolysis cell. Also, the hydrodynamic regime through $\mathrm{H}_{2}$ bubbles generation depend on applied current density, as a key of the coagulation performances to assure the reaction and mixing steps by. The current densities applied to electrocoagulation process of $10 \mathrm{~A} \cdot \mathrm{m}^{-2}, 15 \mathrm{~A} \cdot \mathrm{m}^{-2}$ and $20 \mathrm{~A} \cdot \mathrm{m}^{-2}$ were selected according to our previous results [15] reported for the individual removal of arsenic from water. The initial parameters of the water treated by EC process were: As(III) concentration was about $300 \mu \mathrm{g} \cdot \mathrm{L}^{-1}, 40 \mathrm{mg} \cdot \mathrm{L}^{-1}$ humic acid, $25 \mathrm{mg} \cdot \mathrm{L}^{-1}$ sodium chloride, $25 \mathrm{mg} \cdot \mathrm{L}^{-1}$ sodium sulphate and $\mathrm{pH}$ of 6.77 .

In fig. 1(a)-(d) are presented the results of arsenic and humic acid removal at each current density for 60 minutes' electrolysis time, the iron theoretical dose calculated by Faraday's law and specific energy consumption evolution.

For individual removal of arsenic at a current density of $10 \mathrm{~A} \cdot \mathrm{m}^{-2}$, a concentration below $10 \mu \mathrm{g} \cdot \mathrm{L}^{-1}$ As was reached after 10 minutes of electrocoagulation [15]. For all tested current densities of 10, 15 and $20 \mathrm{~A} \cdot \mathrm{m}^{-2}$ (see fig. 1(a)), in the presence of a high content of humic acid (i.e., $40 \mathrm{mgL}^{-1}$ ), the time required to reach the arsenic concentration under the safety limit recommended by WHO was 60 minutes. The humic acid removal efficiency recorded at the end of the electrolysis time was between 84 and $94 \%$. At the current density of $10 \mathrm{~A} \cdot \mathrm{m}^{-2}$ the DOC was reduced from $9.74 \mathrm{mg} \mathrm{L}^{-1}$ to $1.49 \mathrm{mg} \mathrm{L}^{-1}$, with an efficiency of $85 \%$, by which the legal limit is met $\left(3 \mathrm{mgC} \cdot \mathrm{L}^{-1}\right)$. 


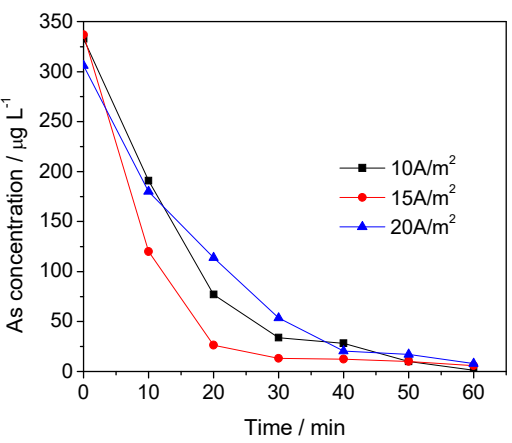

(a)

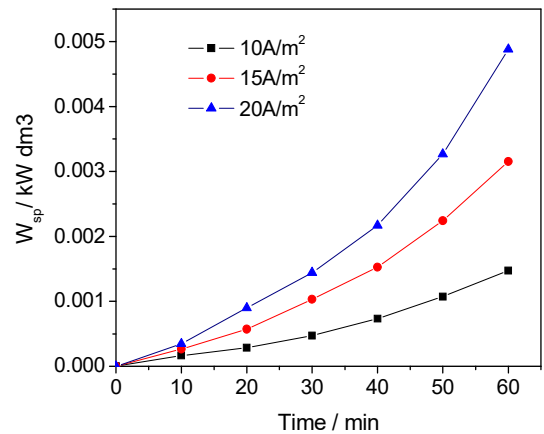

(c)

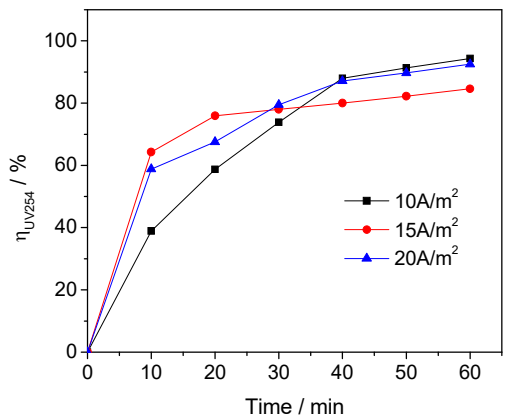

(b)

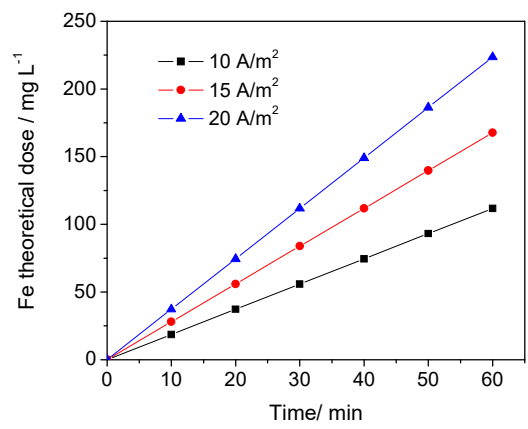

(d)

Figure 1: (a) As concentration, (b) HA removal efficiency, (c) specific energy consumption and (d) Fe theoretical dose evolution at different current

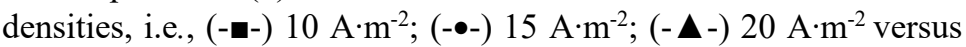
electrolysis time.

The economic aspects are reflected by specific energy consumption (fig. 1c) and iron electrodes dissolution (fig. 1d) for each current density along EC process, both parameters increasing with the applied current and voltage on the EC cell (eqns (1) and (4)). Also, the risk of the higher residual concentration of iron in the treated water is increased. Taking into consideration the EC process efficiencies for removing arsenic and humic acid from water, correlated to the specific energetic consumption and the theoretical quantity of dissolved iron into water, the current density of $10 \mathrm{~A} \cdot \mathrm{m}^{-2}$ was chosen as optimal for further EC tests.

\subsection{Influence of initial As concentration on As and HA simultaneous removal}

The initial arsenic concentrations were chosen in order to cover the stringent problem existent in the natural water sources from Pannonia Basin used for drinking water supply characterized by high concentration of arsenic $[15,18]$. 
In Figures 2(a) and (b) the influence of the initial concentration of arsenic on the EC efficiency in terms of As and HA simultaneous removal are shown. The EC process was conducted at a current density of $10 \mathrm{~A} \cdot \mathrm{m}^{-2}$, in the presence of the $25 \mathrm{mg} \cdot \mathrm{L}^{-1} \mathrm{NaCl}$ as supporting electrolyte for an operational time of 30 minutes.

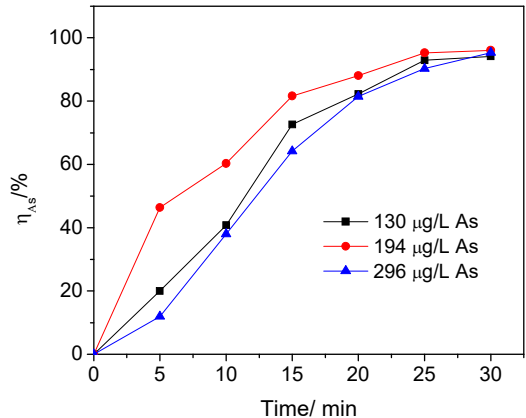

(a)

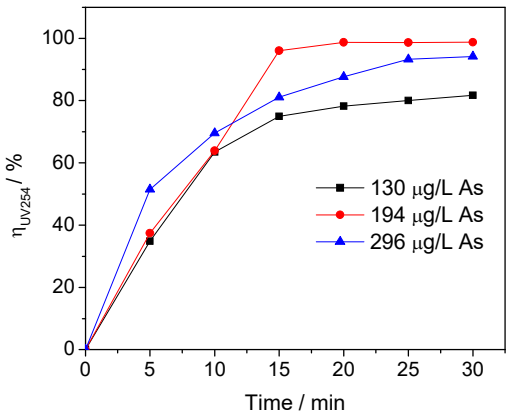

(b)

Figure 2: (a) As concentration, (b) HA removal efficiency evolution function of initial As concentration: (-口-) $130 \mu \mathrm{g} \cdot \mathrm{L}^{-1},(-\bullet-) 194 \mu \mathrm{g} \cdot \mathrm{L}^{-1},(-\boldsymbol{\Delta}-)$ $276 \mu \mathrm{g} \cdot \mathrm{L}^{-1}$ into electrolysis cell; current density of $10 \mathrm{~A} \cdot \mathrm{m}^{-2}$, initial $\mathrm{pH}$ of 6.8 , HA concentration of $20 \mathrm{mg} \cdot \mathrm{L}^{-1} ; \mathrm{NaCl} 25 \mathrm{mg} \cdot \mathrm{L}^{-1}$.

An operation time of 25 minutes was sufficient to reach a residual arsenic concentration below $10 \mu \mathrm{g} \cdot \mathrm{L}^{-1}$ at for the water samples characterized by arsenic concentration of 130 and $194 \mu \mathrm{g} \cdot \mathrm{L}^{-1}$, in the presence of HA concentration of $20 \mathrm{mg} \cdot \mathrm{L}^{-1}$. However, the removal of arsenic from water rich in arsenic was limited by the presence of sterically hindering HA [4]. The individual removal of arsenic from water with an initial As concentration of $256 \mu \mathrm{g} \cdot \mathrm{L}^{-1}$ at a current density of $10 \mathrm{~A} \cdot \mathrm{m}^{-2}$, the target arsenic residual concentration under the limit of $10 \mu \mathrm{g} \cdot \mathrm{L}^{-1}$ was achieved after 10 minutes of EC [15]. The important influence exercised by the presence of HA requires further tests in order to establish the optimal operation conditions for treatment of As and HA rich water, probably a higher dose of iron and mixing time should be required.

A summary of the recorded efficiencies after 30 minutes of EC for the waters with different initial arsenic concentration is presented in Table 1.

The DOC removal efficiencies smaller than the one recorded through $\mathrm{UV}_{254}$ absorbance indicate ability of the EC process to fraction the high HA molecular weight into more hydrophilic organic molecules, the more difficult to be removed through the EC process [14]. As we expected, the specific energy consumption was not influenced by the initial concentration of arsenic (fig. 3) along the EC process. 
Table 1: As, DOC and UV at $254 \mathrm{~nm}$ absorbance efficiencies recorded after 30 minutes of EC.

\begin{tabular}{|c|c|c|c|c|c|c|}
\hline $\begin{array}{c}\text { EC } \\
\text { time }\end{array}$ & As & $\boldsymbol{\eta}_{\text {As }}$ & DOC & $\boldsymbol{\eta}_{\text {DOC }}$ & $\mathbf{U V}_{\mathbf{2 5 4}}$ & $\boldsymbol{\eta}_{\text {HA }}$ \\
\hline $\min$ & $\mu \mathrm{g} / \mathrm{L}$ & $\%$ & $\mathrm{mg} / \mathrm{L}$ & $\%$ & & $\%$ \\
\hline 0 & $\mathbf{1 3 0}$ & & 4.94 & & 0.423 & \\
\hline 30 & 7.61 & 94.15 & 1.53 & 69.03 & 0.124 & 70.68 \\
\hline 0 & $\mathbf{1 9 4}$ & & 4.63 & & 0.405 & \\
\hline 30 & 8.67 & 95.53 & 0.55 & 88.08 & 0.005 & 98.76 \\
\hline 0 & $\mathbf{2 7 6}$ & & 5.625 & & 0.346 & \\
\hline 30 & 12.90 & 95.33 & 1.571 & 72.07 & 0.024 & 93.18 \\
\hline
\end{tabular}

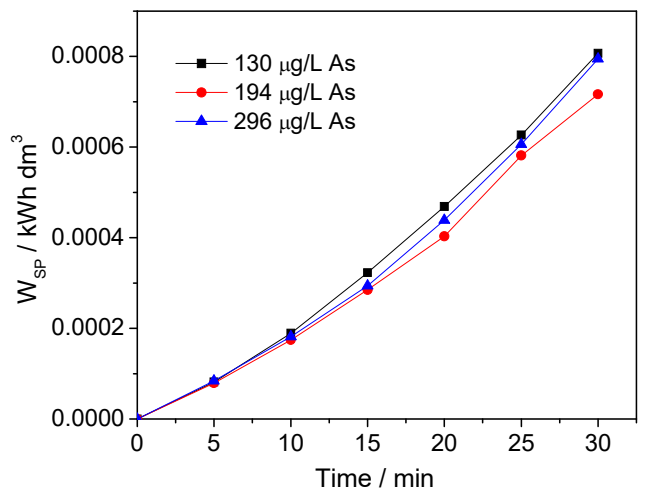

Figure 3: Specific energy consumption evolution function of initial As concentration: (-口-) $130 \mathrm{mg} \cdot \mathrm{L}^{-1},(-\bullet-) 194 \mu \mathrm{g} \cdot \mathrm{L}^{-1},(-\mathbf{\Delta}-) 276 \mu \mathrm{g} \cdot \mathrm{L}^{-1}$ into electrolysis cell; current density of $10 \mathrm{~A} \cdot \mathrm{m}^{-2}$, initial $\mathrm{pH}$ of 6.8 , HA concentration of $20 \mathrm{mg} \cdot \mathrm{L}^{-1} ; \mathrm{NaCl} 25 \mathrm{mg} \cdot \mathrm{L}^{-1}$.

\subsection{Influence of humic acid concentration on As and HA simultaneous removal}

The same operational conditions applied to study the effect of the different initial arsenic concentrations on EC process were used in order to determine the influence of high initial concentration of HA on the simultaneous removal of As and HA from the water samples with an arsenic concentration of $300 \mu \mathrm{g} \cdot \mathrm{L}^{-1}$ subjected to EC process. The EC time was prolonged from 30 to 60 minutes for the water with higher HA concentration, because 30 minutes proved to not be sufficient in order to rich a residual concentration of arsenic below $10 \mu \mathrm{g} \cdot \mathrm{L}^{-1}$. The obtained results show that a concentrations higher than $20 \mathrm{mg} \cdot \mathrm{L}^{-1} \mathrm{HA}$, corresponding to a DOC 
around $5 \mathrm{mg} \cdot \mathrm{L}^{-1}$ influence the removal of arsenic through EC in terms of process rate. The EC rate was higher in the first 30 minutes in the samples with less humic acid (fig. 4a), but the target concentration for residual arsenic $\left(<10 \mu \mathrm{g} \cdot \mathrm{L}^{-1}\right)$ was achieved after 35 minutes in both cases. As expected, the HA removal efficiency was affected by the HA initial concentration, for the tested rich arsenic water. EC applied for a water characterized by arsenic concentration of $300 \mathrm{mg} \cdot \mathrm{L}^{-1}$ and HA concentration of $40 \mathrm{mg} \cdot \mathrm{L}^{-1} \mathrm{HA}$, revealed a removal efficiency of $84.21 \%$ for $\mathrm{UV}_{254}$ absorbance after 60 minutes of electrolysis, and the steady state was not reached. In the less concentrated sample in HA, i.e., $20 \mathrm{mg} \cdot \mathrm{L}^{-1}$ the steady state was reached after 25 minutes of EC, for a HA removal efficiency of $94.28 \%$ (fig. 4(b)).

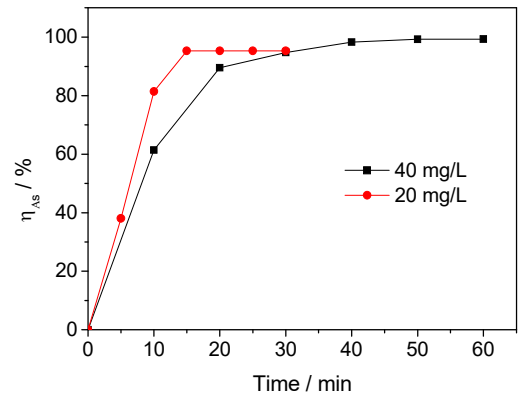

(a)

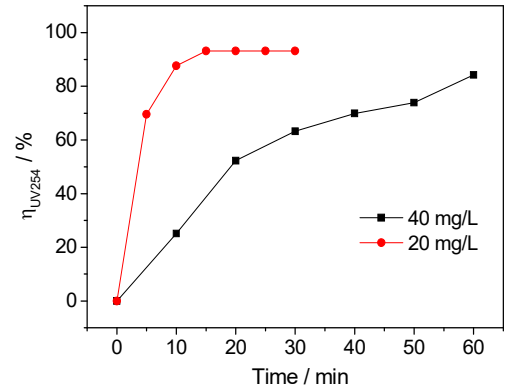

(b)

Figure 4: (a) As concentration, (b) HA removal efficiency evolution function of

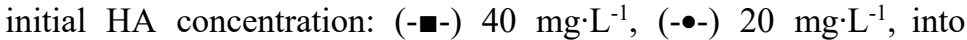
electrolysis cell; current density of $10 \mathrm{~A} \cdot \mathrm{m}^{-2}$, initial $\mathrm{pH}$ of 6.8 , As concentration of $300 \mathrm{mg} \cdot \mathrm{L}^{-1} ; \mathrm{NaCl} 25 \mathrm{mg} \cdot \mathrm{L}^{-1}$.

\subsection{Influence of chloride and sulphate on As and HA simultaneous removal}

In order to simulate the groundwater composition, three different water matrices were tested by EC process for arsenic and NOM rich water characterized by arsenic concentration $300 \mu \mathrm{g} \cdot \mathrm{L}^{-1}$ and humic acid $40 \mathrm{mg} \cdot \mathrm{L}^{-1}$. The sodium chloride of $25 \mathrm{mg} \cdot \mathrm{L}^{-1}$ and sodium sulphate of $25 \mathrm{mg} \cdot \mathrm{L}^{-1}$ (regarded also as supporting electrolytes for EC process) were added individual and in their mixture. The initial water $\mathrm{pH}$ was 6.37 .

A slightly negative influence of sulphate presence was recorded in terms of removal efficiency after 60 minutes EC time, i.e. $75.7 \%$ for arsenic and $77.3 \%$ for $\mathrm{HA}$ in comparison with the EC process conducted in the presence of chloride. The chloride ions added into water allowed reaching a removal efficiency of $99.0 \%$ for arsenic removal and $84.2 \%$ for HA removal in the same operational condition (fig. 5). Chloride ions could exhibit an activation effect on the iron dissolution in comparison with $\mathrm{SO}_{4}{ }^{2-}$ that has an inhibition effect on the anode oxidation, while influenced the precipitates formed during EC. 


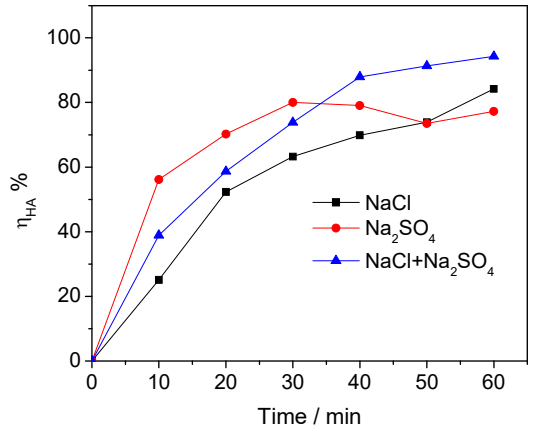

(a)

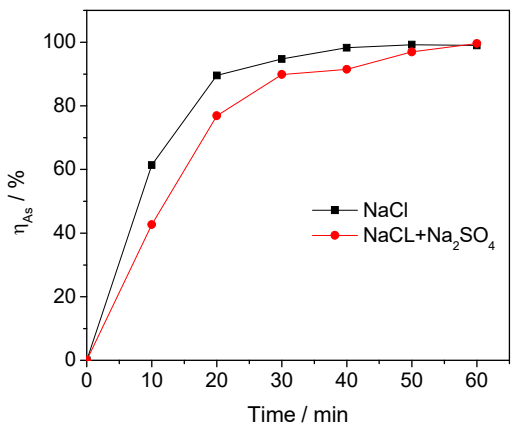

(b)

Figure 5: (a) HA and (b) As removal efficiencies in the presence of different supporting electrolytes i.e., (--) $\mathrm{NaCl},(-\bullet-) \mathrm{Na}_{2} \mathrm{SO}_{4}$, and (- $\left.\mathbf{\Delta}-\right)$ mixture of $\mathrm{NaCl}$ and $\mathrm{Na}_{2} \mathrm{SO}_{4}$ versus electrolysis time.

Having in view the real scenario of groundwater, the next test was performed in the presence of a mixture of sulphate and chloride, each of them at a concentration of $25 \mathrm{mg} \cdot \mathrm{L}^{-1}$. As we expected, the recorded efficiencies were slightly decreased in comparison with the simple chloride concentration along EC process, but at the end of the electrolysis time, the As removal efficiency was of $99.6 \%$, and the HA removal reach an efficiency of $94.3 \%$. These results are encouraging for further practical application on real water.

\subsection{EC sludge characteristics}

Sludge resulted along EC process represent an important aspect either for its valorisation and to elucidate some mechanistic aspects of the EC process. The sludge consists of the co-precipitated and adsorbed arsenic and organic matter onto formed ferric hydroxide/oxy-hydroxide. In fig. 6, the SEM image shows an amorphous structure and the Energy Dispersive X-Ray (EDX) analysis confirms the presence of removed arsenic from water [17].

\section{Conclusions}

This study was performed as a prerequisite step for a further pilot plant design in order to treat groundwater characterised by various concentrations of arsenic and natural organic matter for drinking purpose. The experiments were conducted as batch EC studies to assess the influence of various operational parameters as current density, initial arsenic and humic acid concentration, electrolysis time, presence of sulphate and chloride on the simultaneous removal of arsenic and 


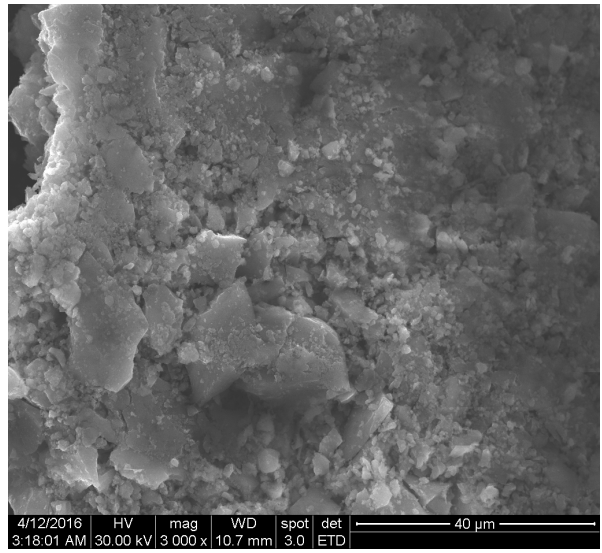

(a)

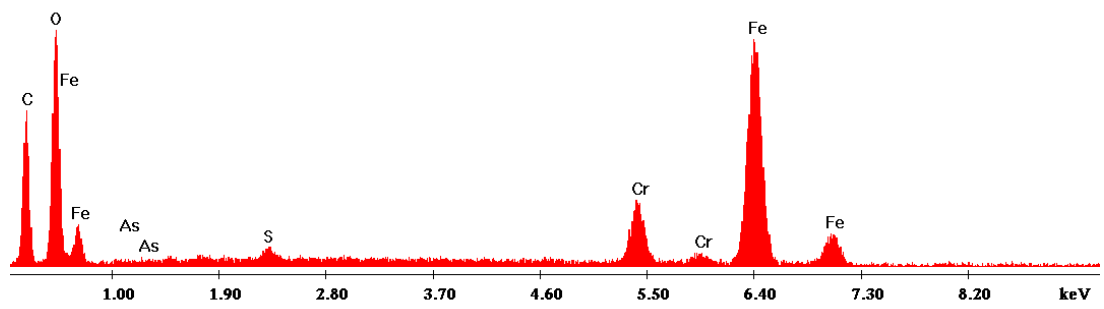

(b)

Figure 6: (a) SEM image and (b) EDX spectra of EC dried sludge.

humic acid from water. A current density of $10 \mathrm{~A} \cdot \mathrm{m}^{-2}$ was established as optimum, successfully reaching the arsenic concentration below $10 \mu \mathrm{g} \cdot \mathrm{L}^{-1}$, recommended by the World Health Organization as the safety limit for drinking water. The presence of simultaneous arsenic and HA in water influenced EC performance. Some sludge characteristics were determined through SEM micrograph and EDX spectra revealing the amorphous structures of arsenic and humic acid complexes coating the surface of iron oxy-hydroxides formed along EC process. For groundwater characterized by $300 \mu \mathrm{g} \cdot \mathrm{L}^{-1}$ As and $40 \mathrm{mg} \cdot \mathrm{L}^{-1}$ humic acid and in the presence of sulphate and chloride, a simultaneous removal efficiency of $99.6 \%$ for As and $94.3 \%$ for HA was achieved after 60 minutes of EC. The great potential of iron anodes to be applied for simultaneous removal of arsenic and NOM from contaminated groundwater was demonstrated in order to integrate EC process into the groundwater treatment flow at pilot scale.

\section{Acknowledgements}

This work was supported partially by a grant of the Romanian National Authority for Scientific Research, CNCS - UEFISCDI, project number PN-II-ID-165/2011, partially by PNII-PCCA-60/2012. 


\section{References}

[1] IARC monographs on the evaluation of carcinogenic risks to humans, Arsenic, metals, fibres, and dusts. International Agency for Research on Cancer: Lyon, 100 C, 2012.

[2] Loom, M.S., Fitzgerald, E.F., Kim, K., Neamtiu I. \& Gurzau, E.S., Spontaneous pregnancy loss in humans and exposure to arsenic in drinking water. International Journal of Hygiene and Environmental Health, 213, pp. 401-413, 2010.

[3] World Health Organization, Arsenic in Drinking-water Background document for development of WHO Guidelines for Drinking-water Quality, $\mathrm{WHO} / \mathrm{SDE} / \mathrm{WSH} / 03.04 / 75 / \mathrm{Rev} / 1$, http://www.who.int/water_sanitation he alth/water-quality/guidelines/chemicals/arsenic.pdf.

[4] Watson, M.A., Aleksandra Tubic, A., Agbaba, J., Nikic, J., Maletic, S., Jazic, J.M. \& Dalmacija B., Response surface methodology investigation into the interactions between arsenic and humic acid in water during the coagulation process. Journal of Hazardous Materials, 312, pp. 150-158, 2016.

[5] Rao, P., Mak, M.S.H., Liu, T., Lai, K.C.K. \& Lo, I.M.C., Effects of humic acid on $\operatorname{arsenic}(\mathrm{V})$ removal by zero-valent iron from groundwater with special references to corrosion products analyses. Chemosphere, 75, pp. 156-162, 2009.

[6] Flores O.J., Nava J.N., Carreño G., Elorza E. \& Martínez F., Arsenic removal from groundwater by electrocoagulation in a pre-pilot-scale continuous filter press reactor. Chemical Engineering Science, 97, pp. 1-6, 2013.

[7] Guzmán A., Nava J.L., Coreño O., Rodríguez I. \& Gutiérrez S., Arsenic and fluoride removal from groundwater by electrocoagulation using a continuous filter-press reactor. Chemosphere, 144, pp. 2113-2120, 2016.

[8] Kobya M., Demirbas E. \& Ulu F., Evaluation of operating parameters with respect to charge loading on the removal efficiency of arsenic from potable water by electrocoagulation. Journal of Environmental Chemical Engineering, 4, pp. 1484-1494, 2016.

[9] Kobya, M., Akyol, A., Demirbas, E. \& Oncel, M.S, Removal of arsenic from drinking water by batch and continuous electrocoagulation processes using hybrid Al-Fe plate electrodes. Environmental Progress \& Sustainable Energy, 33, pp. 131-140, 2014.

[10] Vlaicu, I., Pop, A. Manea, F. \& Radovan, C., Degradation of humic acid from water by advanced electrochemical oxidation method, Water Science and Technology: Water Supply, 11(1), pp. 85-95, 2011.

[11] Dubrawski, K.L. \& Mohseni, M., In-situ identification of iron electrocoagulation speciation and application for natural organic matter (NOM) removal. Water Research, 47(14), pp. 5371-5380, 2013.

[12] Kobya, M., Gebologlu, U., Ulu, F., Oncel, S. \& Demirbas, E., Removal of arsenic from drinking water by the electrocoagulation using $\mathrm{Fe}$ and $\mathrm{Al}$ electrodes. Electrochimica Acta, 56, pp. 5060-5070, 2011. 
[13] Li, L., Li, J., Shao, C., Zhanga, K., Yua, S., Gaoa, N., Deng, Y. \& Yin, D., Arsenic removal in synthetic ground water using iron electrolysis, Separation and Purification Technology, 122, pp. 225-230, 2014.

[14] Mohora, E., Roncevic, S., Agbaba, J., Aleksandra Tubic A., Mitic, M., Klašnja, M. \& Dalmacija B., Removal of arsenic from groundwater rich in natural organic matter (NOM) by continuous electrocoagulation /flocculation (ECF). Separation and Purification Technology, 136, pp. 150156, 2014.

[15] Pop, A., Baciu, A., Wanko, G., Bodor, K., Vlaicu, I. \& Manea, F., Assessment of electrocoagulation process application in arsenic removal from drinking water. Environmental Engineering and Management Journal, in press.

[16] Baciu, A, Pop, A., Bodor, K., Vlaicu, I. \& Manea, F., Assessment of electrocoagulation process for drinking water treatment. Environmental Engineering and Management Journal, 14, pp. 1347-1354, 2015.

[17] Kobya, M., Ulu, F., Ugur Gebologlu, U., Demirbas, E. \& Oncel M.S., Treatment of potable water containing low concentration of arsenic with electrocoagulation: Different connection modes and $\mathrm{Fe}-\mathrm{Al}$ electrodes, Separation and Purification Technology, 77, pp. 283-293, 2011.

[18] Butts C.D., Bloom M.S., Neamtiu I.A., Surdu S. \& Pop C., Atanasiu D., Fitzgerald E.F., Gurzau E.S., A pilot study of low-moderate drinking water arsenic contamination and chronic diseases among reproductive age women in Timis County, Romania. Environmental Toxicology and Pharmacology, 40, pp. 1001-1004, 2015. 